\title{
Prevalence of HPV in the oral cavity of HIV seropositive Indian women undergoing HAART
}

\author{
Jaya Mukherjee ${ }^{1 *}$, Ritwik Dahake², Deepa Das ${ }^{1}$, Gopal Sharma', Bhagyashri Purandare ${ }^{1}$, Abhay Chowdhary ${ }^{2}$ \\ From 2nd International Science Symposium on HIV and Infectious Diseases (HIV SCIENCE 2014) \\ Chennai, India. 30 January - 1 February 2014
}

\section{Background}

Oral manifestations (such as warts) of HIV infection are evident of disease progression, occurring in $30-80 \%$ of affected population. Recent evidence indicates that Human Papillomavirus (HPV) related diseases are increased in the oral cavity of HIV seropositive individuals irrespective of HAART. This study was undertaken to evaluate prevalence of oral HPV infection in Indian HIV seropositive women with/without oral warts.

\section{Methods}

Detection of HPV was carried out from saliva of 60 women divided into equal groups of HIV seropositive with/without warts and age/sex matched healthy controls with/without warts by nested PCR using consensus primers MY09/11 and GP5+/6+ for L1 gene followed by sequencing and sequence analysis. The sequences were typed using the HPV L1 typing tool available on http:// pave.niaid.nih.gov/\#pavic.

\section{Results}

Only one sample was detected to be positive for HPV (prevalence of 6.67\%) and was from the HIV seropositive women with warts group. The HPV serotype was determined to be the low risk non-oncogenic HPV Type 6 by the L1 typing tool and multiple sequence alignment.

\section{Conclusion}

While this was a preliminary study to determine prevalence of HPV in HIV seropostive women, our study has determined a positive correlation with multiple warts and oral sex as factors associated with presence of HPV. Our study also questions whether HAART has a beneficial

\footnotetext{
* Correspondence: drjaya_mukherjee@yahoo.co.in

'Department of Oral Medicine Diagnosis and Radiology, YMT Dental College and Hospital, Navi Mumbai-410210, Maharashtra, India

Full list of author information is available at the end of the article
}

impact on HPV induced cancer. We are of the opinion that this study is the first of its kind in Indian women and emphasize that extensive studies are necessary to establish the incidence of HPV in HIV seropositive population from India.

\section{Authors' details}

'Department of Oral Medicine Diagnosis and Radiology, YMT Dental College and Hospital, Navi Mumbai-410210, Maharashtra, India. ${ }^{2}$ Department of Virology, Haffkine Institute, Mumbai-400012, Maharashtra, India.

Published: 27 May 2014

\section{doi:10.1186/1471-2334-14-S3-E34}

Cite this article as: Mukherjee et al:: Prevalence of HPV in the oral cavity of HIV seropositive Indian women undergoing HAART. BMC Infectious Diseases 2014 14(Suppl 3):E34.
Submit your next manuscript to BioMed Central and take full advantage of:

- Convenient online submission

- Thorough peer review

- No space constraints or color figure charges

- Immediate publication on acceptance

- Inclusion in PubMed, CAS, Scopus and Google Scholar

- Research which is freely available for redistribution
() Biomed Central 